УДК 925 : 159.923

Ivashkevych Eduard, Doctor of Psychology, Professor of the Department of General Psychology and Psychological diagnostics of Rivne State University of the Humanities (Rivne, Ukraine)

natasha1273@ukr.net

Prymachok Lyudmyla, PhD in Pedagogical Sciences, Professor's assistant of the Department of human health and physical rehabilitation of Educational and Scientific Institute of Public Health of National University of Water Management and Nature usage (Rivne, Ukraine)

primachok73@ukr.net

\title{
THE DEVELOPMENT OF SOCIAL INTELLIGENCE OF THE PERSON IN THE PARADIGM OF PROFESSIONAL GROWTH
}

\section{Summary}

In this article the authors tell about social intelligence and the role of the latter in teaching activities. The latter was analyzed in terms of the impact on its productivity, efficiency and conditions of optimization, professional growth of the person. It should be noted that in the pedagogical activity the concept of "productivity" is considered from the point of view of two positions: functional and psychological productivity. The functional productivity of the teacher's activity is as a clearly constructed system of didactic methods and techniques, the basic updating of which are communicative skills. In such a way psychological productivity is the newness of the personality of a student, the level of his/her social adaptation that will contribute to the process of the development of social intelligence.

It was emphasized that in the process of professional activity, the tendency is to reflect the object of cognition from many positions, which subsequently manifests itself outside of this activity and becomes a professional habit, indicating a high level of the development of social intelligence.

Consequently, the productivity of teaching activity directly depends on the effectiveness of the knowledge of a teacher on the personality of students, that is, 
depends on socio-perceptual peculiarities of both - a teacher and schoolchildren. To our mind, social intelligence of a teacher is updated due to the mechanisms of knowledge of a teacher the students' personal qualities and characteristics. One of such mechanisms is pedagogical social-perceptual stereotyping.

Also, a very important role for the process of studying by a teacher the person of a student takes the teacher's ability to empathy, which, on the one hand, increases the adequacy of a teacher's perception on schoolchildren, and, on the other hand, affects the establishment of effective, positive contacts with students. In other words, in the process of pedagogical activity empathy provides a transition from the monologue (subject-object) to the dialogic (subject-subject) strategy of interpersonal interaction. From the standpoint of the dialogic content of interpersonal interaction empathy provides awareness and understanding of students' experience, therefore, empathy can be considered as a purely emotional phenomenon. In this case in the process of mental development empathic experience is formed as emotional cognitive systems, in structural schemes of which the most complex forms of empathy were mediated by knowledge.

Social intelligence of the person is a kind of psychological instrument for providing a person with his/her own effective life, therefore, he/she is organized in a special way, but not as if it is separated from the social activity of the subject. In this case, the activity of the person, his/her position of subjectivity in relation to the society appears not only and not so much that the person contributes to a somewhat general, integral and social, but that the person is able to outside the direct coordination with all representatives of the society to create its own system of ways of interaction with other people, so-called socially determined interpretation complex. Such approach has to solve the essence of social intelligence and it is particularly important for pedagogical practice.

Key words: social intelligence, pedagogical practice, teaching activities, professional activity, professional growth, interpretation complex, empathy, pedagogical social-perceptual stereotyping, functional productivity, psychological productivity. 
Івашкевич Едуард Зенонович, доктор психологічних наук, доцент, професор кафедри загальної психології та психодіагностики Рівненського державного гуманітарного університету (Рівне, Україна)

Примачок Людмила Леонтіївна, кандидат педагогічних наук, доцент, доцент кафедри здоров'я людини і фізичної реабілітації Навчальнонаукового інституту охорони здоров'я Національного університету водного господарства та природокористування (Рівне, Україна)

\section{РОЗВИТОК СОЦАЛЬНОГО ІНТЕЛЕКТУ ОСОБИСТОСТІ В ПАРАДИГМІ ПРОФЕСІЙНОГО ЗРОСТАННЯ}

\section{Анотація}

В статті йдеться про соціальний інтелект та роль останнього у педагогічній діяльності. Останню проаналізовано в аспекті ii продуктивності, ефективності і умов оптимізації. При цьому зазначено, що у педагогічній діяльності поняття «продуктивність» розглядається 3 двох позицій: як функціональна i психологічна продуктивність тощо. Функціональними продуктами діяльності педагога є чітко вибудована система дидактичних методів і прийомів, базовими актуалізаторами яких є комунікативні вміння, а психологічними - новоутворення особистості учня, рівень соціальної адаптації, які сприятимуть становленню соціального інтелекту.

Наголошено, що в процесі здійснення професійної діяльності виявляється тенденція відображувати об’єкт пізнання з багатьох позицій, що згодом виявляється поза цією діяльністю і переходить у професійну звичку, що свідчить про високий рівень розвитку соціального інтелекту.

Визначено, що продуктивність педагогічної діяльності безпосередньо залежить від ефективності пізнання педагогом особистості учнів, тобто соціально-перцептивних особливостей як вчителя, так і школярів. Зазначено, що соціальний інтелект педагога актуалізується завдяки механізмам пізнання педагогом особистості учня. Одним із таких механізмів $є$ педагогічна соціально-перцептивна стереотипізація. 
В статті зазначено, що досить важливу роль для процесу пізнання педагогом особистості учня приймає здатність вчителя до співпереживання, тобто, - емпатія, що, з одного боку, підвищує адекватність сприйняття педагогом школярів, а, з іншого боку, впливає на встановлення ефективних, позитивних контактів з учнями. Іншими словами, в процесі педагогічної діяльності емпатія забезпечує перехід від монологічної (суб'єкт-об'єктної) до діалогічної (суб'єкт-суб'єктної) стратегії міжособистісної взаємодії. 3 позицій діалогічного змісту міжособистісної взаємодії емпатія забезпечує усвідомлення і розуміння переживань учнів, тому емпатію можна розглядати як суто емоційне явище. У зв'язку з цим в процесі психічного розвитку емпатійні переживання формуються як емоційні когнітивні системи, в структурних схемах яких найбільш складні форми емпатії опосередковані знанням.

Соціальний інтелект індивіда розглянуто як своєрідний психологічний інструмент забезпечення людиною власної ефективної життєдіяльності, тому він організований особливим чином, а не існує ніби відірвано від соціальної активності суб'єкта. При цьому активність індивіда, його позиція суб’єктності по відношенню до соціуму виявляється не тільки й не стільки в тім, що людина робить внесок в дещо загальне, інтегрально-соціумне, а в тому, що індивід здатен поза безпосереднього узгодження 3 усіма представниками свого соціуму створювати власну систему способів взаємодії 3 іншими людьми, так званий соціально зумовлений інтерпретаційний комплекс. Наголошено, що такий підхід до розв'язання сутності соціального інтелекту є особливо важливим для педагогічної практики.

Ключові слова: соціальний інтелект, педагогічна практика, педагогічна діяльність, професійна діяльність, професійне зростання, інтерпретаційний комплекс, емпатія, педагогічна соціально-перцептивна стереотипізація, функціональна продуктивність, психологічна продуктивність. 
Ивашкевич Эдуард Зенонович, доктор психологических наук, доцент, профессор кафедры общей психологии и психодиагностики Ровенского государственного гуманитарного университета (Ровно, Украина)

Примачок Людмила Леонтьевна, кандидат педагогических наук, доцент, доцент кафедры здоровья человека и физической реабилитации Учебнонаучного института здравоохранения Национального университета водного хозяйства и природопользования (Ровно, Украина)

\section{РАЗВИТИЕ СОЦИАЛЬНОГО ИНТЕЛЛЕКТА ЛИЧНОСТИ В ПАРАДИГМЕ ПРОФЕССИОНАЛЬНОГО СТАНОВЛЕНИЯ}

\section{Аннотация}

В статье идёт речь о социальном интеллекте и его роли в педагогической деятельности. Последнюю проанализировано в аспекте её производительности, эффективности и условий оптимизации. При этом отмечено, что в педагогической деятельности понятие «производительность» рассматривается с двух позиций: как функциональная и психологическая производительность. Функциональными продуктами деятельности педагога можно считать чётко выстроенную систему дидактических методов и приёмов, базовыми актуализаторами которых являются коммуникативные умения, а психологическими - новообразования личности ученика, уровень социальной адаптивности, способствующие становлению социального интеллекта.

Отмечено, что в процессе осуществления профессиональной деятельности проявляется тенденция отображать объект познания с учётом многих позиций, что впоследствии оказывается вне этой деятельностью и переходит в профессиональную привычку, и это свидетельствует о высоком уровне развития социального интеллекта.

Определено, что производительность педагогической деятельности напрямую зависит от эффективности познания педагогом личности учащихся, то есть - социально-перцептивных особенностей как учителя, так и школьников. Отмечено, что социальный интеллект педагога 
актуализируется благодаря механизмам познания педагогом личности учащегося. Одним из таких механизмов является педагогическая социальноперцептивная стереотипизация.

В статье указано, что важную роль для процесса познания педагогом личности ученика играет способность учителя к сопереживанию, то есть эмпатия, что, с одной стороны, повышает адекватность восприятия педагогом школьников, a, с другой стороны, влияет на установление эффективных, положительных контактов с учениками. Иными словами, в процессе педагогической деятельности эмпатия обеспечивает переход от монологической (субъект-объектной) к диалогической (субъект-субъектной) стратегии межличностного взаимодействия. С позиций диалогического содержания межличностного взаимодействия эмпатия обеспечивает осознание и понимание переживаний учащихся. В связи с этим в процессе личностного развития эмпатийные переживания формируются как эмоциональные когнитивные системы, в структурных схемах которых наиболее сложные формы эмпатии опосредованы знанием.

Социальный интеллект индивида рассмотрено как своеобразный психологический инструмент обеспечения человеком собственной эффективной жизнедеятельности, поэтому он имеет особую организацию, а не существует как бы в отрыве от социальной активности субъекта. При этом активность индивида, его позиция субъектности по отношению к социуму проявляется не только и не столько в том, что человек делает вклад в нечто общее, интегрально-социумное, а в том, что индивид способен вне непосредственного согласования со всеми представителями своего социума создавать собственную систему способов взаимодействия с другими людьми, так называемый социально обусловленный интерпретационный комплекс. Отмечено, что такой подход к решению сущности социального интеллекта является особенно важным для педагогической практики.

Ключевые слова: социальный интеллект, педагогическая практика, педагогическая деятельность, профессиональная деятельность, 
профессиональное становление, интерпретационный комплекс, эмпатия, педагогическая социально-перцептивная стереотипизация, функциональная производительность, психологическая производительность.

Problem's statement and the actuality of the research. The research of social intelligence from time to time was out of the sphere of the interests of researchers. This state of affairs was largely due to failure, even in the case of different attempts to determine the features of social intelligence, to show the differences in the structure of social intelligence from academic or abstract point of view. The difficulties faced by scholars were likely to be attributed comparing with the peculiarities of psychological approaches that mostly captured attention either according to cognitive or procedural aspects of social intelligence. It should also be noted that empirical studies of social intelligence, had being taken place in foreign psychology, were organized, above all, in the paradigm of a psychometric scientific approach (despite the fact that scientific developments are rather wellbalanced and within the limits of other theoretical approaches). So, the problem of social intelligence, also its diagnostics are very actual nowadays.

The purpose of the research. In this article we've to analyze nature of social intelligence of the person, to describe cognitive-verbal methods of diagnostics of social intelligence, to show a test method to diagnostic the level of the development of social intelligence, to propose our own definition of social intelligence of the person, to describe the empiric research and to analyze the results of the development of social intelligence of teachers of primary school.

Presenting the material of the research. Consequently, some researchers, for example R.Thorndike [15], actualized the multidimensional nature of social intelligence. However, in empirical researches of social intelligence, attention was paid, first of all, to the cognitive aspects of social intelligence, such as social perception (in his researches R. Thorndike sometimes uses "social intelligence" and "social perception" as synonyms). In order to determine other cognitive characteristics of social intelligence, scientists relied, as a rule, on the results of 
verbal measurement procedures. The assessment of the same constitutional aspects associated with social intelligence was also carried out by using verbal psychodiagnostic methods (for example, by using self-report).

In the 1980's other researches - M.Ford and M.Tisak [9] - noted that for the complex description of social intelligence scientists would use one of three criteria, such as: 1) the ability to decode social information; 2) the effectiveness or adaptability of social behavior (illustrative subject-subject constructs are so called "behavioral outcomes", for the explication of which, above all, we need social and cognitive skills); 3) any social skill that can be measured. These criteria, in turn, have been reflected in the methods used to diagnostics of social intelligence. Such methods are: cognitive-verbal, behavioral and non-verbal.

Now we'd like to describe cognitive-verbal methods of diagnostics of social intelligence. Diagnostics of social intelligence is usually carried out using traditional test methods that also determine so called "general intellectual level of the person" (IQ in tests). However, additional methods are also used to help identify individual peculiarities of social intelligence. One of the first and most well-known method which was used to diagnostic the level of the development of the person's social intelligence had been a test, developed by George Washington (GWSIT). It consists of a number of subtasks that assess critical decisions made by a person in social interaction situations, determine the mental state of a person after performing test tasks, assess the degree of remembering names and people, the behavior of the person, also sense of humor. The last criteria in this test was the most important.

According to the Model of Intelligence of J.Guilford [10], M. O'Sullivan and J.Guilford [14], D.Day [8] developed a test method to diagnostic the level of the development of social intelligence. These tests were used to determine the effectiveness of cognitive activity of people, which scientists defined as the ability to evaluate events and situations critically in a great degree. These tests revealed the ability of the person to recognize external social signals, including facial expression, change of intonation, posture, facial expressions and gestures. Having 
examined three hundred and six students of high school, M. O'Sullivan and J.Guilford proved that the data determining the level of the development of social intelligence differed significantly from the assessment corresponding to the level of abstract cognitive abilities. However, at the stage of conducting additional empirical studies, totally opposite results were obtained.

Similar experiments were conducted by a group of scientists led by H.Smith [13]. Researchers have used various methods to determine the level of the development of social intelligence and showed different ways to assess the level of academic intelligence of the person (as respondents in the experiment involved students). The level of the development of academic intelligence was determined by the scale of life experience proposed by the Shipley-Hartford Institute. At the same time verbal and abstract interpretations were assessed, as well as the subscale of the vocabulary volume "WAIS-R". Diagnostics of the level of the development of social intelligence envisaged the usage of four tests of determining social intelligence and providing factor analysis for the evaluation of results described by researchers; assessment of social skills (emotional expression, emotional sensitivity, emotional control, social expression, social control, etc.); test for the evaluation of implicit ethical skills assessing the adequacy of person's behavior in social situations of interpersonal interaction.

Similar results on the usage of methods for diagnostics of social intelligence were obtained by M.Karnes [11] and D.Keating [12]. For example, M.Karnes used the "Social Intuition Test" developed by him, the essence of the tasks of which were following: people are asked to evaluate problem situations and choose the best, to their opinion, four alternative descriptions of each situation. In the experiments of M.Karnes he also used the "Test of determination of the result", which was based on the theory of moral development of L.Kolberg. As a criterion for better diagnostics M.Karnes applied the index of social maturity based on selfassessment of the effectiveness of individual social presentation of himself/herself.

However, the scientist did not find a positive correlation between the data of social intelligence. The results of factor analysis confirmed that the level of the 
development of social intelligence according to the basic characteristics differed from the level of the development of academic intelligence. All measurements made by M.Karnes [11] and H.Smith [13] were oriented on a verbal principle of diagnostics of social intelligence. The latter led to the inability to determine the difference between levels of the development of abstract and social intelligence.

According to these conclusions of scientists we are sure that the development of social intelligence can take a place only in the paradigm of professional grows of the person, in the sphere of his/her professional activity. In our research as respondents we'd like to take teachers of secondary schools. We'll try to explain our position. So, speaking about social intelligence and the role of the latter in teaching activities, the latter should be analyzed in terms of the impact on its productivity, efficiency and conditions of optimization. It should be noted that in the pedagogical activity the concept of "productivity" is considered from the point of view of two positions: functional and psychological productivity. The functional productivity of the teacher's activity is as a clearly constructed system of didactic methods and techniques, the basic updating of which are communicative skills. In such a way psychological productivity is the newness of the personality of a student, the level of his/her social adaptation that will contribute to the process of the development of social intelligence.

Also, in the process of professional activity, the tendency is to reflect the object of cognition from many positions, which subsequently manifests itself outside of this activity and becomes a professional habit, indicating a high level of the development of social intelligence. Thus, O.Kukosyan [6, p. 100-113] established the dependence of knowledge by the teacher of other people, depending on the length of service and age, and this dependence manifests itself both on figurative and conceptual levels. So, the scientist identified professional standards and stereotypes of knowledge of a teacher according to other people.

Taking into account the specifics of each particular object, pedagogical activity is built upon the laws of communication. In any classifications the structure of communication in the foreground appears its cognitive aspect, which largely 
determines the productivity of teaching activities. Thus, S.Kondratieva [5] revealed the regularities of the influence of the level of productivity on the understanding of the behavior of the partner in communication, which indicates the actualization of social intelligence. Scientists found that teachers with a low level of pedagogical activity can only perceive external manifestations of the communication of partners, also their behavior without analyzing its goals and motives. However, teachers with a high level of productivity of pedagogical activities can understand the deep essence of the personality-integrational properties of the person, identifying the goals and motives of his/her behavior.

Consequently, the productivity of teaching activity directly depends on the effectiveness of the knowledge of a teacher on the personality of students, that is, depends on socio-perceptual peculiarities of both - a teacher and schoolchildren.

To our mind, social intelligence of a teacher is updated due to the mechanisms of knowledge of a teacher the students' personal qualities and characteristics. One of such mechanisms is pedagogical social-perceptual stereotyping. For the first time this mechanism was investigated in the experiments of B.Ananiev [1], in which positive and negative stereotyping of the students' personal qualities and characteristics were determined. Also, B.Ananiev identified the influence of evaluative standard stereotypes on social-perceptual stereotyping. It was proved that the negative influence on interpersonal interaction in the pedagogical process had stereotypes that were taking into account an absolute, unchanging character, but for each teacher there were subjective evaluative stereotypes and the teacher focused on their content for the purpose of the actual subjective assessment of the student's personality. Then subsequently, this mechanism of pedagogical activity will facilitate the study of personal qualities and characteristics from a professional point of view. In turn, all this indicates a significant level of the development of social intelligence of a teacher.

Also, a very important role for the process of studying by a teacher the person of a student takes the teacher's ability to empathy, which, on the one hand, increases the adequacy of a teacher's perception on schoolchildren, and, on the other hand, 
affects the establishment of effective, positive contacts with students. In other words, in the process of pedagogical activity empathy provides a transition from the monologue (subject-object) to the dialogic (subject-subject) strategy of interpersonal interaction. From the standpoint of the dialogic content of interpersonal interaction empathy provides awareness and understanding of students' experience, therefore, empathy can be considered as a purely emotional phenomenon. In this case G.Ball noted [2] that in the process of mental development empathic experience is formed as emotional cognitive systems, in structural schemes of which the most complex forms of empathy were mediated by knowledge.

So, taking into account the researches done by M.Smulson [7], L.Zasekina [4] we think that social intelligence of the person is a kind of psychological instrument for providing a person with his/her own effective life, therefore, he/she is organized in a special way, but not as if it is separated from the social activity of the subject. In this case, the activity of the person, his/her position of subjectivity in relation to the society appears not only and not so much that the person contributes to a somewhat general, integral and social, but that the person is able to outside the direct coordination with all representatives of the society to create its own system of ways of interaction with other people, so-called socially determined interpretation complex. Such approach has to solve the essence of social intelligence and it is particularly important for pedagogical practice. Indeed, in the structure of the person social intelligence already has a certain repertoire of stereotypical methods, techniques, means that allow the man to establish contact with other people and to provide optimal interaction, even when, for example, cognitive empathy is reduced, or if the subject is insufficiently developed his/her ability to generalize and rationalize, or do not coincide with value orientations, moral and ethical guidance in subjects of social interaction. Social intelligence allows a deeper understanding of another person. At the same time, we predict that there is a certain set of basic dynamic structures of social intelligence that allow a 
person to adequately and empathically interact with other actors of social interaction.

We believe that, unlike to so-called "general" intelligence, social intelligence of each person is oriented not only to the average social norms. Its norm is defined as the process of orientation to the social, moral and ethical standards of a close to human environment, and the opposite tendency is the desire of the person to occupy his/her own place in the society, which makes it different for understanding the subject valuable meaning, his/her own uniqueness. The contradiction between stereotyping and individualization of social intelligence is so called activator of its formation and development. From the psychological point of view, the difference between stereotyping and individualization of social intelligence is not absolute. Based on different examples of a real life, one can argue about some "opium" in the ratio of stereotyped and unique sense. In this case when the balance moves towards stereotypes, social intelligence of a person does not perform an adaptive function or change, and social intelligence is almost not formed (we mean the low level of its development). Also with the help of domination of unique content (or the adoption of the person, uniqueness for giving individual decisions), the person demonstrates valuable frames, cognition that he/she has acquired value, characterizing the development of the person in the period of age crises, describing personal conflicts or situations of cognitive dissonance.

Methods and methodical instrumentation of the research. At this stage of the empirical research were participated 395 teachers of secondary schools of different regions of Ukraine and 8 directors of these schools. At the beginning of the research we formulated the hypotheses that the level of the development of social intelligence of the teacher of secondary school will depend on the professional category (which he/she has; the category will show the degree of professionalisms of the teacher), the type of discipline of this teacher (to which cycle of disciplines belongs this or that subject), and (it is the main) from the psychological type of the personality and from the gender characteristics of the person. For the convenience of describing the results of the research (hence the description of those results that 
have or do not have a statistically significant difference among representatives of different groups), all respondents were distributed by large and small experimental groups. So, when the results of respondents within a single large experimental group had a statistically significant difference, they were described separately, taking into account their formation within small groups; in the case when there was no such difference, the results of all respondents were described in the paradigm of one large specially formed group. In such a way, all 403 respondents were divided into the following groups:

1) S group - 103 teachers of the III-d and the II-d categories (professional experience is from 5 to 10 years, the age is up to 30 years). This group includes: 56 teachers of secondary schools № 5, № 15 of Rivne town, 23 teachers of Shpanivska and Alexandria secondary schools of Rivne region, 24 teachers of secondary schools № 45, № 96 of Odessa city. In turn, all teachers of this group were divided into subgroups, depending on the discipline they teach:

- S1 group includes 34 primary school teachers (of which 4 teachers are men and 30 ones are women);

- S2 group includes 35 teachers of teenagers who teach the natural sciences and humanities (of which 17 teachers are men and 18 ones are women);

- S3 group includes 34 teachers of senior pupils of the physical and mathematical cycle (of which 17 teachers are men and 17 ones are women);

2) $\mathrm{N}$ group includes 108 teachers of the I-st category (professional experience is from 10 to 15 years, the age is from 30 to 35 years), among them there are 47 teachers of secondary schools № 5, № 15 of Rivne town, 30 teachers of Shpanivska and Alexandria secondary schools of Rivne region, 31 teacher of secondary schools № 45, № 96 of Odessa city. Teachers of N group were divided into such micro-groups:

- N1 group includes 39 primary school teachers (all of them are women);

- N2 group includes 37 teachers of teenagers who teach the natural sciences and humanities (among them there are 17 men and 20 women); 
- N3 group includes 32 teachers of senior pupils of the physical and mathematical cycle (16 of them are men and 16 are women);

3) $M$ group includes 110 teachers of the highest category (professional experience is from 15 years and more, age is from 35 years old and elder); among them there are 55 teachers of secondary schools № 5, № 15 of Rivne town, 22 teachers of Shpanivska and Alexandria secondary schools of Rivne region, 33 teachers of secondary schools № 45, № 96 of Odessa city. Teachers of M group were divided into such micro-groups:

- M1 group includes 26 teachers of primary school (all of them are women);

- M2 group includes 42 teachers of teenagers who teach subjects of physicalmathematical cycle (there are 22 men and 20 women);

4) $\mathrm{P}$ group includes 74 teachers-methodists and eight directors of secondary schools (their professional experience is 35-40 years, age is 40-47 years old), among them there are 32 teachers of secondary schools № 5, № 15 of Rivne town, 13 teachers of Shpanivska and Alexandria secondary schools of Rivne region, 29 teachers of secondary schools № 45, № 96 of Odessa city. This group also includes 8 directors of secondary schools (among them there are directors of schools, noted above, and also the director of Zdolbuniv schools № 5, 7 of Rivne region). Teachers of $\mathrm{P}$ group were divided into such micro-groups:

- P1 group includes 13 primary school teachers (all of them are women);

- P2 group includes 30 teachers of teenagers who teach the natural sciences and humanities (among them there are 12 men and 18 women);

- P3 group includes 31 teachers of teenagers and senior pupils of the physical and mathematical cycle (among them there are 15 men and 16 women);

- P4 group includes 8 directors of secondary schools (among them there are 4 men and also 4 women).

Distribution of teachers into groups and micro-groups was carried out using the method of randomization (technology of pair design), which allowed us to equalize the number of men and women in each micro-group (except for micro-groups, which included primary school teachers, because there were no men among this 
category of teachers). With the aim to diagnose the level of the development of social intelligence of teachers we used the test of J.Guilford and M. O'Sullivan "Research of Social Intelligence", adapted by E.Myhailova [3].

At this article we'll describe the results obtained by us at first stage of our experiment. So, we'll analyze the results of the development of social intelligence of teachers of primary school.

The results of the research and their discussion. The teachers of the primary school have the high level of the development of the most significant skills and qualities of a teacher, which promote the implementation of optimal contacts in the team: respect for other people, humane and tactful attitude towards them; knowledge and understanding of individual characteristics of subordinates and colleagues in well-organized work, dependence of their behavior on the characteristics of different professional situations; the ability to be attentive and benevolent to the suggestions and opinions of the subordinates, to consult with them in any cases; adequate understanding of the inner world of another person, the manifestation of empathy in the process of communication; openness, trust, sincerity in contacts with different people; ability to understand the best spiritual and moral qualities of a person and to rely on them in mutual relationships; knowledge of norms of managerial and business ethics, ability to use them in specific situations of the professional activity; the ability to influence the emotional attitude of a person, to improve his / her mood with the help of humor, encouraging words and replicas; hardness and stiffness in appropriate (in the opinion of the teacher) cases; a negative attitude to flattery, sobbing, praise.

Teachers of primary school received rather high results for personal and intellectual reflection. This is explained first of all by the fact that the essence of the reflection lies in the fact that a person, referring to the past, as if restoring, rereproducing his/her actions, thoughts, feelings, states - and, in such a way, explores, cognizes and develops himself/herself. Perceiving the other, a person mentally puts himself/herself onto his/her place, while, reproducing his/her actions, thoughts, feelings, states - explores and teachers another person. This is a reflexion 
of a higher level. Perceiving oneself with the eyes of another one, a person attributes to this "another" certain expectations in relations to himself/herself. So, the teacher studies, learns and develops relationships with others.

Analyzing the results of teachers of primary school according to intellectual and personal reflection, we emphasize the cognitive content of the professional thinking of these educators. Reflection, to our mind, is an active, thorough and continuous analysis of people's ideas and beliefs from the point of view on what other consequences can lead to. Therefore, reflection inevitably manifests itself in the process of communication, as in a case of primary school teachers it is a condition and a mechanism of intercourse and effective communication. Reflection determines such personal qualities of a partner as penetration, sensitivity, patience, invaluable acceptance and understanding of another person.

Reflection gives the teacher the idea of how he/she is perceived as a partner in the process of communication, allowing them to adjust their behavior based on this presentation. Reflection ensures mutual understanding and coherence of the actions of partners in the conditions of cooperating, joint activity. We tell about the mechanism of "removal position", that is a mechanism for entering the positions "above" and "out" of this situation.

Also pretty high results teachers of primary school had for empathy, which, in our opinion, also greatly increased the results of the overall assessment of social intelligence. Empathy is a sensation that transmits such a spiritual unity of the person when one person is so imbued with feelings of another one who temporarily identified himself/herself with an interlocutor, as even to mean dissolving in this process. In this deep process there is a mutual understanding. The empathy of teachers of primary school, in our opinion, correlates with extraversion, in addition, the empathy of primary school teachers positively correlates with the female ability of the psyche to get deep knowledge in any period of his/her life.

Thus, empathy as the ability to resonate emotionally on the experiences of another person has a fairly high level of the development of teachers of primary school, which has expanded their high results of social intelligence. The results of 
personal qualities, professional skills of primary school teachers facilitate the development of social intelligence of these teachers, were treated by the procedure of factor analyses. As a result, three basic factors were obtained.

To the first, the most significant factor ( $72,34 \%$ of dispersion), which we called "The factor of communicative competence, empathy and reflection", with the highest factor weight there were included such characteristics: "the ability to empathize" $(0,83)$, "the ability to initiate a favorable moral climate for pedagogical communication" $(0,82)$, "expressive interactive skills" $(0,78)$, “adequate understanding of the inner world of the interlocutor, empathy in communication" $(0,78)$, "communicative abilities" $(0,76)$, "ability to self-examination and selfknowledge" $(0,73)$, "expressive skills" $(0,73)$, "qualities based on the principles of professional ethics and etiquette" $(0,70)$, "personal reflection" $(0,69)$ and others.

The second factor $(21,05 \%$ of dispersion) was named by us as "Prognostic abilities", which included the following characteristics: "the ability to predict a specific result of the activity" $(0,63)$, "the ability to plan and to design" $(0,60)$, "the ability to lead the school team" $(0,54)$, "the ability to predict the development of inter-entity relationships, while using both verbal and non-verbal means, as well as mechanisms of communicative influences - infection, persuasion, suggestion, etc." $(0,53)$, "the ability to plan cognitive activity of students" $(0,53)$, "the ability to predict their own professional development and development of other people" $(0,50)$.

And, finally, the third factor $(6,61 \%$ of dispersion) was called "Axiological one". It includes only three characteristics: "the value relation of the teacher to himself/herself and the personality of the student" $(0,51)$, "the system of personality attitudes, the experience of interpersonal and professional communication and interactions" $(0,49)$, "the ability to organize business communication" $(0,40)$.

Conclusions. Consequently, the factor analysis having been done by us and the results we have made it possible to conclude that teachers of primary school have a "high" or "above the average" level of the development of social intelligence that 
is largely ensured by the level of the development of communicative competence, empathy (for example, its cognitive and predicative forms), and also intellectual and personal reflection.

The process of the development of social intelligence implies that the person simultaneously finds something in the structure of his/her personality and in the personality of others, both typical and unique. Unfortunately, this does not happen if in the structure of social intelligence of a person there are not his/her own uniqueness and stereotypeness.

\section{Literature}

1. Ананьев Б.Г. О соотношении способностей и одарённости [Текст] / Борис Герасимович Ананьев // Проблемы способностей / [под редакцией В.Н. Мясищева]. - № 3. - М., 1962. - С. 15-32.

2. Балл Г.О. Діалогічність як форма існування і розвитку особистості : [монографія] / Г.О. Балл, М.В. Папуча / [за загальною ред. Г.О. Балла, М.В. Папучі]. - Ніжин : Міланик, 2007. - 343 с.

3. Гилфорд Дж., О’Салливен М. Тест «Социальный интеллект» [Электронный ресурс] / Джой Пол Гилфорд, Джон Луи О’Салливен / [в адаптации Елены Сергеевны Михайловой]. - Режим доступа : lib.chdu.edu.ua/pdf/posibnuku/160/41.pdf.

4. Засєкіна Л.В. Профілі значення слова як функція когніції і культури [Текст] / Лариса Володимирівна Засєкіна // Наук. записки Острозької академії. Серія «Психологія і педагогіка». - Острог : Вид-во нац. ун.-ту «Острозька академія», 2010. - С. 66-75.

5. Кондратьева С.В. Учитель - ученик [Текст] / Светлана Витальевна Кондратьева. - М. : Просвещение, 1984. - 80 с.

6. Кукосян О.Г. Профессиональные особенности межличностного познания [Текст] / Ованес Гайкович Кукосян // Вопросы психологии межличностного познания и общения. - Краснодар, 1985. - С. 100-113. 
7. Смульсон М.Л. Психологія розвитку інтелекту : [монографія] / Марина Лазарівна Смульсон // [видання друге, виправлене та доповнене]. - К. : Норадрук, 2003. - 298 с. - (Інститут психології імені Г.С.Костюка АПН України).

8. Day D.H. Infant perception of the invariant size of approaching and re-geding objects [Text] / D.H. Day // Developmental Psychologiy. 1981. - 306 p.

9. Ford M.E., Tisak M.S. A future search of social intelligence [Text] / M.E. Ford, M.S. Tisak // Journal of Educational Psychology. - 1983. - Vol. 75 (2). - P. 196207.

10. Guilford J.P. Is some creative thinking irrational? [Text] / Joy Paul Guilford // Journal of creative behavior. - 1982. - Vol. 16 (3). - P. 151-154.

11. Karnes M.B. The underserved: Our joung gifted children [Text] / M.B. Karnes. - N.-Y., 1986. - 303 p.

12. Keating D.K. A search for social intelligence [Text] / David K. Keating // Journal of Educational Psychology. - Vol. 70. - 1978. - P. 218-233.

13. Smith H.G. Sensitivity Training [Text] / H.G. Smith. - N.-Y., 1970. - 291 p.

14. O'Sullivan M., Guilford J.P. The nature of human intelligence [Text] / J.P. Guilford. - N.-Y. : McGraw-Hill, 1967. - 156 p.

15. Thorndike R.L. Factor analysis of social and abstract intelligence [Text] / Robert Ladd Thorndike // Journal of Educational Psychology. - 1986. - № 27. - P. 231-233.

\section{References transliterated}

1. Anan'ev B.G. O sootnoshenii sposobnostej i odaryonnosti [Tekst] / Boris Gerasimovich Anan'ev // Problemy sposobnostej / [pod redakciej V.N. Myasishheva]. - № 3. - M., 1962. - S. 15-32.

2. Ball H.O. Dialohichnist yak forma isnuvannia i rozvytku osobystosti : [monohrafiia] / H.O. Ball, M.V. Papucha / [za zahalnoiu red. H.O. Balla, M.V. Papuchi]. - Nizhyn : Milanyk, 2007. - 343 s.

3. Gilford Dzh., O’Salliven M. Test «Social'nyj intellekt» [E'lektronnyj resurs] / Dzhoj Pol Gilford, Dzhon Lui O’Salliven / [v adaptacii Eleny Sergeevny Mixajlovoj]. - Rezhim dostupa : lib.chdu.edu.ua/pdf/posibnuku/160/41.pdf. 
4. Zasiekina L.V. Profili znachennia slova yak funktsiia kohnitsii i kultury [Tekst] / Larysa Volodymyrivna Zasiekina // Nauk. zapysky Ostrozkoi akademii. Seriia «Psykholohiia i pedahohika». - Ostroh : Vyd-vo nats. un.-tu «Ostrozka akademiia», 2010. - S. 66-75.

5. Kondrat'eva S.V. Uchitel' - uchenik [Tekst] / Svetlana Vital'evna Kondrat'eva. M. : Prosveshhenie, 1984. $-80 \mathrm{~s}$.

6. Kukosyan O.G. Professional'nye osobennosti mezhlichnostnogo poznaniya [Tekst] / Ovanes Gajkovich Kukosyan // Voprosy psixologii mezhlichnostnogo poznaniya i obshheniya. - Krasnodar, 1985. - S. 100-113.

7. Smulson M.L. Psykholohiia rozvytku intelektu : [monohrafiia] / Maryna Lazarivna Smulson // [vydannia druhe, vypravlene ta dopovnene]. - K. : Noradruk, 2003. - 298 s. - (Instytut psykholohii imeni H.S.Kostiuka APN Ukrainy).

8. Day D.H. Infant perception of the invariant size of approaching and re-geding objects [Text] / D.H. Day // Developmental Psychologiy. 1981. - 306 p.

9. Ford M.E., Tisak M.S. A future search of social intelligence [Text] / M.E. Ford, M.S. Tisak // Journal of Educational Psychology. - 1983. - Vol. 75 (2). - P. 196207.

10. Guilford J.P. Is some creative thinking irrational? [Text] / Joy Paul Guilford // Journal of creative behavior. - 1982. - Vol. 16 (3). - P. 151-154.

11. Karnes M.B. The underserved: Our joung gifted children [Text] / M.B. Karnes. - N.-Y., 1986. - 303 p.

12. Keating D.K. A search for social intelligence [Text] / David K. Keating // Journal of Educational Psychology. - Vol. 70. - 1978. - P. 218-233.

13. Smith H.G. Sensitivity Training [Text] / H.G. Smith. - N.-Y., 1970. - 291 p.

14. O'Sullivan M., Guilford J.P. The nature of human intelligence [Text] / J.P. Guilford. - N.-Y. : McGraw-Hill, 1967. - 156 p.

15. Thorndike R.L. Factor analysis of social and abstract intelligence [Text] / Robert Ladd Thorndike // Journal of Educational Psychology. - 1986. - № 27. - P. 231-233. 